\title{
Monitoring of Leopard Moth, Zeuzera pyrina, on Apple Trees in Albehira Governorate
}

\author{
Howayda M. Tawfik
}

\begin{abstract}
Field studies were conducted through three successive seasons 2015, 2016 and 2017 to monitor the different stages of the leopard moth in apple orchards in Kafr Eldawar, Albehira Governorate. During Spring, number of active galleries (larvae) / 10 trees ranged from 2.5 to 3.8 during the three seasons. The exuvia was not detected during the period from March 25 to April 25 and began to appear at May 4 (5.0, 6.0 and 5.5 exuvia / 10 trees during 2015, 2016 and 2017, respectively). Number of larvae / 10 trees reached to the maximum during the period from August 25 to September 4, where it was 15.5 and 16.0 during 2015 , 14.5 and 14.3 during 2016 and 15.3 and 14.0 during 2017. On the other hand, exuvia reached the highest numbers at starting period of Summer season and reached to the least number at July 25. During Autumn season, there was a slight fluctuations in the number of larvae (active gallaries) / 10 trees and it was ranged between 11.3 to 22.3 , at the three successive seasons. Exuvia were not detected in the Autumn and Winter during the three seasons. This study is useful to determine the suitable time for application of mechanical and chemical control of larvae and attracting pheromones and mating disruption in the integrated pest management programs for leopard moth.
\end{abstract}

Keywords: Leopard moth; Zeuzera pyrina; Exuvia; Active galleries.

\section{INTRODUCTION}

Apple is considered the most important deciduous fruit in the world. The leading producer in Africa is South Africa, followed by Egypt and Kenya (Ntakyo et al., 2013). The cultivated total area in Egypt reached around 72,000 Fed. produced about 600,000 tons (Yehia et al., 2016). Apple is attacked by many pests, between them the leopard moth, Zeuzera pyrina L. (Lepidoptera: Cossidae).

The leopard moth was first found in the United States in New-Jersey in 1887 (Howard and Chittenden, 1916). Leopard moth a dangerous wood borer attacks many fruit trees such as apple, pear and olive causing significant yield loss (Ntakyo et al., 2013; Hegazi et al., 2015). The leopard moth larvae begin boring into the shoots and spread gradually into branches throughout the entire plant causing the tree to wither and die. Pupation and adult emergence take place one or two years later (Tonini et al., 1986).

DOI: 10.21608/asejaiqjsae.2021.153845

${ }^{1}$ Plant Protection Research Institute, Alexandria, Egypt.

Received January 25, 2021, Accepted March 04, 2021
Control of the leopard moth borer depended mainly on using pheromones, mass trapping, mating disruption (Avilla and Bosch 2001; Abed El-Hadi et al., 2005) and the biological control (Abdel-Kawy et al., 1992; Patanita, 2006). The management of leopard moth by smallholder farmers at orchards depends on the application of organic and synthetic insesticides in different areas (Chouinard et al., 2016). However, the timing and choosing of the suitable control method is very important for the successful control of the leopard moth.

Monitoring of the leopard moth different stages would be very useful for the timing and choosing of the control methods. Therefore, the aim of this study was to monitor the different stages of the leopard moth in apple orchards in Kafr Eldawar, Albehira Governorate through three successive seasons 2015, 2016 and 2017.

\section{MATERIALS AND METHODS}

Monitoring of leopard moth larvae and exuvia was carried out in an apple orchard located in Kafr Eldawar, Beheira Governorate, Northern Egypt. Apple orchard was cultivated with Anna cultivar trees (20 years old). All cultural practices were carried out according to "good agricultural practice". The total experiment area, 4 fed., was divided into 4 replicates (1 fed. Each). Fifteen trees from each replicate were chosen randomly and investigated for the infestation (larvae and exuvia) by the leopard moth weekly. The experiment took place during three successive seasons 2015, 2016 and 2017. Results were calculated and presented as the number of larvae or exuvia / 10 trees \pm SD.

\section{RESULTS AND DISCUSSIONS}

\section{RESULTS}

The presence of leopard moth active galleries (larvae) and exuvia / 10 apple trees in Spring during three successive seasons 2015, 2016 and 2017 is shown in Table (1, 2 and 3). The number of active galleries (larvae) / 10 trees ranged from 2.5 to 3.8 during the three seasons. The larvae was detected during all the Spring period from March 25 to June 18. The exuvia was not detected during the period from March 25 to April 25. The exuvia began to appear at May 4 (5.0, 6.0 and 5.5 exuvia / 10 trees during 2015, 2016 and 2017, respectively). The presence of exuvia were continued 
and increased in the remaining period of Spring tell June 18, and reached to $18.0,15.0$ and 16.3 exuvia / 10 trees during 2015, 2016 and 2017 seasons, respectively.

The larvae were not active during the starting period of the Summer season from June 25 to July 25 and began to appear again at August 4. The number of larvae / 10 trees reached to the maximum during the period from August 25 to September 4, where it was 15.5 and 16.0 during 2015 (Table 1), 14.5 and 14.3 during 2016 (Table 2) and 15.3 and 14.0 during 2017
(Table 3). Exuvia reached the highest numbers at starting period of Summer season and reached to the least number at July 25 . Number of exuvia reached to 21.3, 17.8 and 18.3 / 10 trees at June 25 in 2015, 2016 and 2017, respectively (Tables 1, 2 and 3). On the other hand, number of exuvia / 10 trees were 13.0, 8.0 and 8.3 at July 25 in the three successive seasons 2015, 2016 and 2017, respectively. The exuvia was not detected in the remaining period of Summer at the three seasons 2015, 2016 and 2017.

Table 1. Occurrence of leopard moth active galleries and exuvia on apple trees during 2015

\begin{tabular}{|c|c|c|c|c|c|c|}
\hline \multirow{2}{*}{ Month } & \multirow{2}{*}{ Stage } & \multicolumn{4}{|c|}{ Mean of active galleries and exuvia / 10 trees at } & \multirow{2}{*}{$\begin{array}{c}\text { Overall } \\
\text { mean } \pm \mathrm{SE}\end{array}$} \\
\hline & & 4 day & 11 day & 18 day & 25day & \\
\hline \multirow{2}{*}{ January } & active galleries & $16.3 \pm 0.4$ & $14.8 \pm 0.4$ & $13.8 \pm 0.2$ & $10.0 \pm 0.1$ & $13.7 \pm 2.7$ \\
\hline & exuvia & 0.0 & 0.0 & 0.0 & 0.0 & 0.0 \\
\hline \multirow{2}{*}{ February } & active galleries & $10.8 \pm 0.3$ & $9.5 \pm 0.3$ & $7.5 \pm 0.3$ & $10.8 \pm 0.3$ & $8.8 \pm 1.6$ \\
\hline & exuvia & 0.0 & 0.0 & 0.0 & 0.0 & 0.0 \\
\hline \multirow{2}{*}{ March } & active galleries & $6.0 \pm 0.2$ & $5.3 \pm 0.2$ & $3.8 \pm 0.1$ & $2.8 \pm 0.1$ & $4.5 \pm 1.4$ \\
\hline & exuvia & 0.0 & 0.0 & 0.0 & 0.0 & 0.0 \\
\hline \multirow{2}{*}{ April } & active galleries & $3.0 \pm 0.2$ & $3.3 \pm 0.2$ & $2.5 \pm 0.1$ & $2.8 \pm 0.1$ & $2.9 \pm 0.3$ \\
\hline & exuvia & 0.0 & 0.0 & 0.0 & 0.0 & 0.0 \\
\hline \multirow{2}{*}{ May } & active galleries & $3.0 \pm 0.1$ & $3.3 \pm 0.2$ & $2.5 \pm 0.1$ & $2.8 \pm 0.1$ & $2.9 \pm 0.3$ \\
\hline & exuvia & $5.0 \pm 0.3$ & $5.8 \pm 0.2$ & $7.3 \pm 0.3$ & $7.8 \pm 0.3$ & $6.5 \pm 1.3$ \\
\hline \multirow{2}{*}{ June } & active galleries & $3.0 \pm 0.2$ & $3.3 \pm 0.2$ & $2.5 \pm 0.1$ & 0.0 & $2.2 \pm 1.5$ \\
\hline & exuvia & $10.3 \pm 0.3$ & $15.8 \pm 0.4$ & $18.0 \pm 0.5$ & $21.3 \pm 0.5$ & $16.4 \pm 4.6$ \\
\hline \multirow{2}{*}{ July } & active galleries & 0.0 & 0.0 & 0.0 & 0.0 & 0.0 \\
\hline & exuvia & $18.0 \pm 0.4$ & $16.3 \pm 0.5$ & $15.0 \pm 0.4$ & $13.0 \pm 0.3$ & $5.6 \pm 2.1$ \\
\hline \multirow{2}{*}{ August } & active galleries & $8.8 \pm 0.4$ & $9.5 \pm 0.3$ & $10.8 \pm 0.4$ & $15.5 \pm 0.4$ & $11.2 \pm 3.0$ \\
\hline & exuvia & 0.0 & 0.0 & 0.0 & 0.0 & 0.0 \\
\hline \multirow{2}{*}{ September } & active galleries & $16.0 \pm 0.3$ & $13.5 \pm 0.2$ & $13.8 \pm 0.4$ & $15.0 \pm 0.3$ & $14.6 \pm 1.2$ \\
\hline & exuvia & 0.0 & 0.0 & 0.0 & 0.0 & 0.0 \\
\hline \multirow{2}{*}{ October } & active galleries & $11.5 \pm 0.3$ & $13.5 \pm 0.2$ & $14.0 \pm 0.4$ & $17.0 \pm 0.4$ & $14.0 \pm 2.3$ \\
\hline & exuvia & 0.0 & 0.0 & 0.0 & 0.0 & 0.0 \\
\hline \multirow{2}{*}{ November } & active galleries & $15.8 \pm 0.4$ & $14.0 \pm 0.5$ & $14.5 \pm 0.4$ & $16.8 \pm 0.5$ & $15.3 \pm 1.3$ \\
\hline & exuvia & 0.0 & 0.0 & 0.0 & 0.0 & 0.0 \\
\hline December & $\begin{array}{c}\text { active galleries } \\
\text { exuvia }\end{array}$ & $\begin{array}{c}17.5 \pm 0.2 \\
0.0 \\
\end{array}$ & $\begin{array}{c}18.3 \pm 0.4 \\
0.0 \\
\end{array}$ & $\begin{array}{c}16.0 \pm 0.3 \\
0.0 \\
\end{array}$ & $\begin{array}{c}16.3 \pm 0.5 \\
0.0 \\
\end{array}$ & $\begin{array}{c}17.0 \pm 1.1 \\
0.0 \\
\end{array}$ \\
\hline
\end{tabular}


Table 2. Occurrence of leopard moth active galleries and exuvia on apple trees during 2016

\begin{tabular}{|c|c|c|c|c|c|c|}
\hline \multirow{2}{*}{ Month } & \multirow{2}{*}{ Stage } & \multicolumn{4}{|c|}{ Mean of active galleries and exuvia / 10 trees at } & \multirow{2}{*}{$\begin{array}{c}\text { Overall } \\
\text { mean } \pm S E\end{array}$} \\
\hline & & 4 day & 11 day & 18 day & 25 day & \\
\hline \multirow{2}{*}{ January } & active galleries & $14.8 \pm 0.3$ & $17.5 \pm 0.3$ & $11.8 \pm 0.2$ & $9.5 \pm 0.3$ & $13.4 \pm 3.5$ \\
\hline & exuvia & 0.0 & 0.0 & 0.0 & 0.0 & 0.0 \\
\hline \multirow{2}{*}{ February } & active galleries & $10.0 \pm 0.2$ & $9.3 \pm 0.2$ & $7.8 \pm 0.3$ & $7.3 \pm 0.2$ & $8.6 \pm 1.3$ \\
\hline & exuvia & 0.0 & 0.0 & 0.0 & 0.0 & 0.0 \\
\hline \multirow{2}{*}{ March } & active galleries & $5.0 \pm 0.1$ & $5.0 \pm 0.1$ & $5.0 \pm 0.1$ & $3.5 \pm 0.2$ & $4.6 \pm 0.8$ \\
\hline & exuvia & 0.0 & 0.0 & 0.0 & 0.0 & 0.0 \\
\hline \multirow{2}{*}{ April } & active galleries & $3.0 \pm 0.2$ & $2.3 \pm 0.1$ & $2.5 \pm 0.1$ & $3.5 \pm 0.2$ & $2.8 \pm 0.5$ \\
\hline & exuvia & 0.0 & 0.0 & 0.0 & 0.0 & 0.0 \\
\hline \multirow{2}{*}{ May } & active galleries & $3.0 \pm 0.1$ & $2.3 \pm 0.1$ & $2.5 \pm 0.1$ & $3.5 \pm 0.2$ & $3.0 \pm 0.6$ \\
\hline & exuvia & $6.0 \pm 0.3$ & $7.0 \pm 0.4$ & $9.8 \pm .04$ & $7.0 \pm .02$ & $6.4 \pm 1.3$ \\
\hline \multirow{2}{*}{ June } & active galleries & $3.0 \pm 0.2$ & $2.3 \pm 0.1$ & $2.5 \pm 0.1$ & 0.0 & $2.0 \pm 1.3$ \\
\hline & exuvia & $8.3 \pm 0.2$ & $16.3 \pm 0.3$ & $15.0 \pm 0.4$ & $17.8 \pm 0.4$ & $14.4 \pm 4.2$ \\
\hline \multirow{2}{*}{ July } & active galleries & 0.0 & 0.0 & 0.0 & 0.0 & 0.0 \\
\hline & exuvia & $20.3 \pm 0.5$ & $14.8 \pm 0.4$ & $14.0 \pm 0.2$ & $8.0 \pm 0.1$ & $14.3 \pm 5.0$ \\
\hline \multirow{2}{*}{ August } & active galleries & $8.3 \pm 0.3$ & $10.5 \pm 0.5$ & $12.0 \pm 0.4$ & $14.5 \pm 0.3$ & 11.32 .6 \\
\hline & exuvia & 0.0 & 0.0 & 0.0 & 0.0 & 0.0 \\
\hline \multirow{2}{*}{ September } & active galleries & $14.3 \pm 0.4$ & $13.3 \pm 0.3$ & $12.8 \pm 0.3$ & $14.5 \pm 0.4$ & $13.7 \pm 0.8$ \\
\hline & exuvia & 0.0 & 0.0 & 0.0 & 0.0 & 0.0 \\
\hline \multirow{2}{*}{ October } & active galleries & $14.0 \pm 0.4$ & $15.5 \pm 0.3$ & $11.3 \pm 0.4$ & $15.8 \pm 0.2$ & $14.2 \pm 2.1$ \\
\hline & exuvia & 0.0 & 0.0 & 0.0 & 0.0 & 0.0 \\
\hline \multirow{2}{*}{ November } & active galleries & $13.8 \pm 0.5$ & $12.5 \pm 0.3$ & $15.8 \pm 0.3$ & $13.8 \pm 0.5$ & $15.1 \pm 2.5$ \\
\hline & exuvia & 0.0 & 0.0 & 0.0 & 0.0 & 0.0 \\
\hline \multirow{2}{*}{ December } & active galleries & $18.3 \pm 0.7$ & $22.3 \pm 0.5$ & $16.5 \pm 0.6$ & $16.0 \pm 0.4$ & $18.3 \pm 2.9$ \\
\hline & exuvia & 0.0 & 0.0 & 0.0 & 0.0 & 0.0 \\
\hline
\end{tabular}

During the Autumn season (September 23 to December 21), there was a slight fluctuations in the number of larvae (active gallaries) / 10 trees and it was ranged between 11.3 to 22.3 , at the three successive seasons (Table 3). Exuvia were not detected in the Autumn season. Larvae started to decrease in the starting of Winter season and reached to the least numbers by the end of Winter during the three season 2015, 2016 and 2017. At December 25, number of larvae were $16.3,16.0$ and 17.0 / 10 trees during 2015, 2016 and 2017, respectively. At March 18 (end of Winter), number of larvae / 10 trees reached to 3.8, 5.0 and 4.3, at 2015, 2016 and 2017, respectively. On the other hand, exuvia were not detected at Winter of the three seasons 2015, 2016 and 2017 (Table 1, 2 and 3). In the three seasons there was fluctuations in the number of active gallaries and exuvia (Fig. 1 and 2). 
Table 3. Occurrence of leopard moth active galleries and exuvia on apple trees during 2017

\begin{tabular}{|c|c|c|c|c|c|c|}
\hline \multirow{2}{*}{ Month } & \multirow{2}{*}{ Stage } & \multicolumn{4}{|c|}{ Mean of active galleries and exuvia / 10 trees at } & \multirow{2}{*}{$\begin{array}{c}\text { Overall } \\
\text { mean } \pm \mathrm{SE}\end{array}$} \\
\hline & & 4 day & 11 day & 18 day & 25day & \\
\hline \multirow{2}{*}{ January } & active galleries & $15.0 \pm 0.4$ & $16.3 \pm 0.3$ & $11.0 \pm 0.2$ & $8.3 \pm 0.2$ & $12.7 \pm 3.7$ \\
\hline & exuvia & 0.0 & 0.0 & 0.0 & 0.0 & 0.0 \\
\hline \multirow{2}{*}{ February } & active galleries & $10.3 \pm 0.4$ & $9.5 \pm 0.2$ & $6.8 \pm 0.1$ & $6.5 \pm 0.1$ & $8.8 \pm 1.6$ \\
\hline & exuvia & 0.0 & 0.0 & 0.0 & 0.0 & 0.0 \\
\hline \multirow{2}{*}{ March } & active galleries & $5.8 \pm 0.3$ & $5.8 \pm 0.1$ & $4.3 \pm 0.1$ & $3.3 \pm 0.2$ & $4.8 \pm 1.2$ \\
\hline & exuvia & 0.0 & 0.0 & 0.0 & 0.0 & 0.0 \\
\hline \multirow{2}{*}{ April } & active galleries & $3.8 \pm 0.2$ & $2.5 \pm 0.1$ & $2.5 \pm 0.1$ & $3.3 \pm 0.2$ & $3.0 \pm 0.6$ \\
\hline & exuvia & 0.0 & 0.0 & 0.0 & 0.0 & 0.0 \\
\hline \multirow{2}{*}{ May } & active galleries & $3.8 \pm 0.2$ & $2.5 \pm 0.1$ & $2.5 \pm 0.1$ & $3.3 \pm 0.2$ & $3.0 \pm 0.6$ \\
\hline & exuvia & $5.5 \pm 0.2$ & $6.0 \pm .2$ & $5.8 \pm 0.2$ & $8.3 \pm 0.2$ & $6.4 \pm 1.3$ \\
\hline \multirow{2}{*}{ June } & active galleries & $3.8 \pm 0.2$ & $2.5 \pm 0.1$ & $2.5 \pm 0.1$ & 0.0 & $2.2 \pm 1.6$ \\
\hline & exuvia & $11.0 \pm 0.5$ & $12.8 \pm 0.4$ & $16.3 \pm 0.4$ & $18.3 \pm 0.6$ & $14.6 \pm 3.3$ \\
\hline \multirow{2}{*}{ July } & active galleries & 0.0 & 0.0 & 0.0 & 0.0 & 0.0 \\
\hline & exuvia & $16.3 \pm 0.3$ & $15.8 \pm 0.3$ & $10.8 \pm 0.2$ & $8.3 \pm 0.2$ & $12.8 \pm 3.9$ \\
\hline \multirow{2}{*}{ August } & active galleries & $9.5 \pm 0.4$ & $11.5 \pm 0.5$ & $13.5 \pm 0.3$ & $13.5 \pm 0.4$ & $12 . .0 \pm 1.9$ \\
\hline & exuvia & 0.0 & 0.0 & 0.0 & 0.0 & 0.0 \\
\hline \multirow{2}{*}{ September } & active galleries & $15.3 \pm 0.5$ & $14.0 \pm 0.3$ & $12.0 \pm 0.4$ & $16.0 \pm 0.3$ & $14.3 \pm 1.8$ \\
\hline & exuvia & 0.0 & 0.0 & 0.0 & 0.0 & 0.0 \\
\hline \multirow{2}{*}{ October } & active galleries & $15.8 \pm 0.3$ & $17.0 \pm 0.5$ & $14.0 \pm 0.3$ & $13.8 \pm 0.3$ & $15.2 \pm 1.5$ \\
\hline & exuvia & 0.0 & 0.0 & 0.0 & 0.0 & 0.0 \\
\hline \multirow{2}{*}{ November } & active galleries & $14.5 \pm 0.4$ & $14.5 \pm 0.4$ & $16.3 \pm 0.4$ & $18.3 \pm 0.4$ & $15.9 \pm 1.8$ \\
\hline & exuvia & 0.0 & 0.0 & 0.0 & 0.0 & 0.0 \\
\hline \multirow{2}{*}{ December } & active galleries & $20.3 \pm 0.3$ & $19.3 \pm 0.6$ & $18.3 \pm 0.5$ & $17.0 \pm 0.3$ & $18.7 \pm 1.4$ \\
\hline & exuvia & 0.0 & 0.0 & 0.0 & 0.0 & 0.0 \\
\hline
\end{tabular}




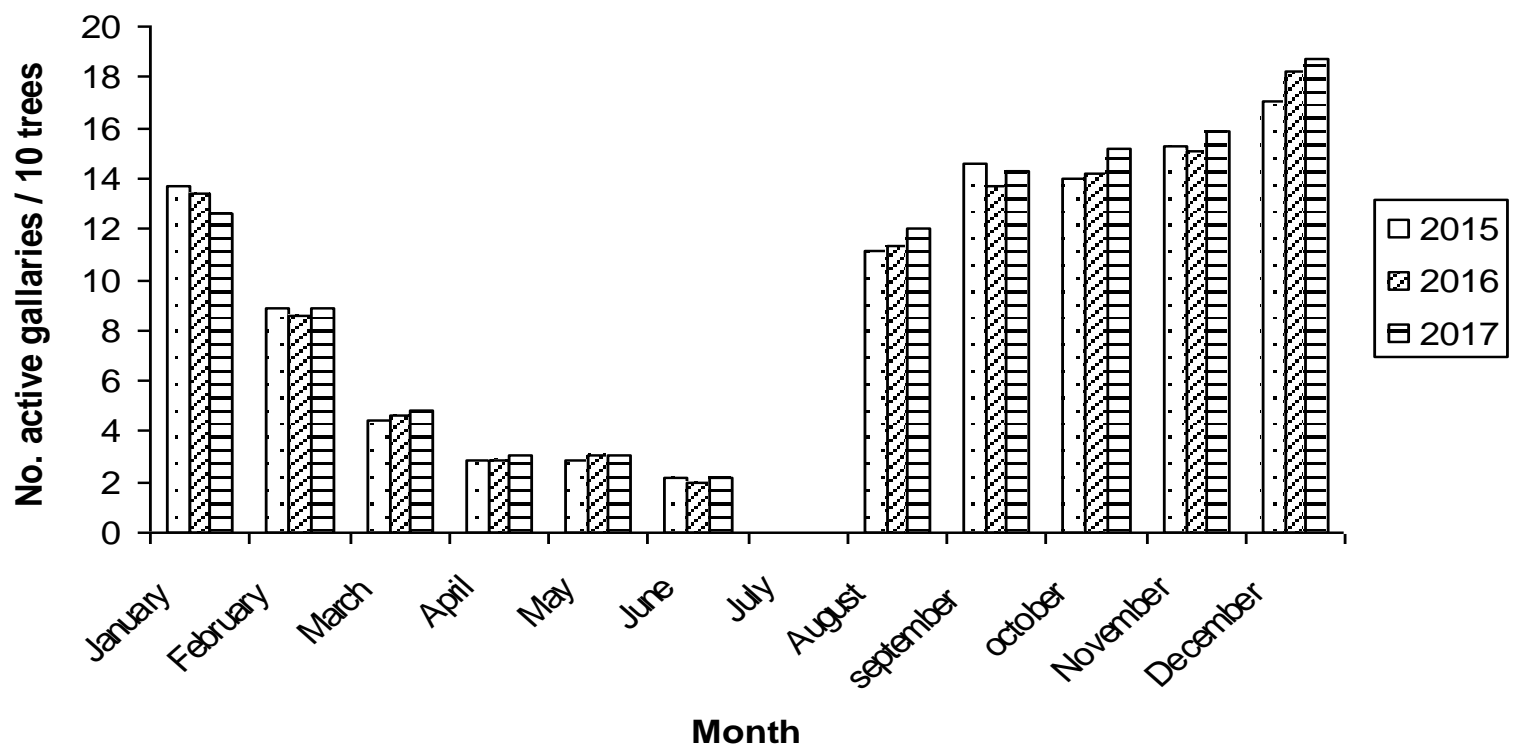

Fig. 1. Occurrence of leopard moth active gallaries in apple trees orchard at Kafr-Eldawar, Albehira governorate

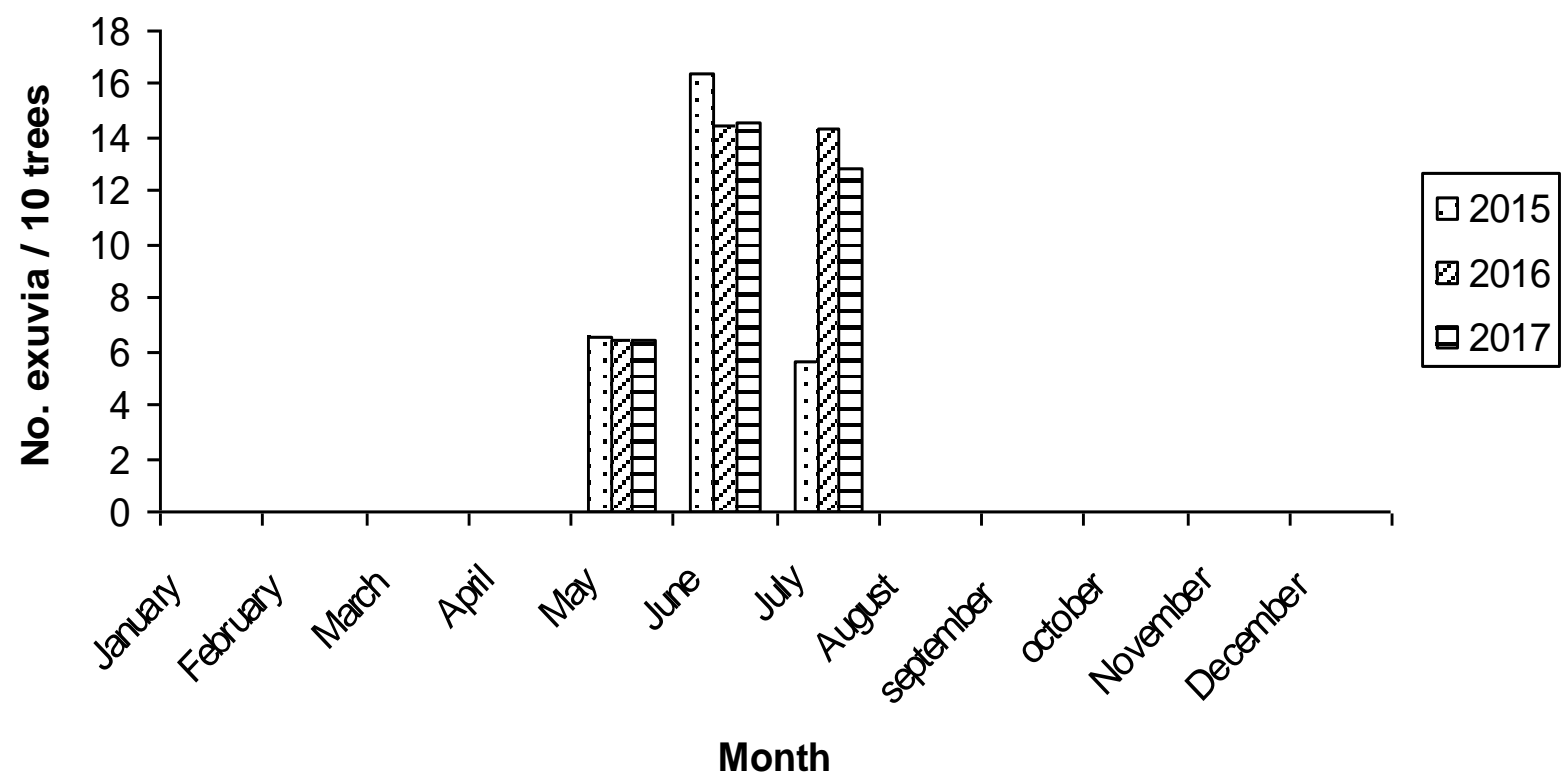

Fig. 2. Occurrence of exuvia moth gallaries in apple trees orchard at Kafr-Eldawar, Albehira governorate

\section{DISCUSSION}

Leopard moth (Lepidoptera: Cossidae) larvae are drilling holes into the stems and branches of tree. The attack of this pest may interrupt the transport of nutrients from the soil to the host plant (Suheri et al.,
2020). The successful control programs of leopard moth depend mainly on the choose of the suitable time and control method. Therefore, the present study was carried out to help those interested in pest control to choose the suitable time and the efficient control method for this 
dangerous insect pest. Results revealed that, the existence of exuvia (excavation of moths) were at May, June and July. Therefore, the suitable control method for this period is using of pheromone trapping and / or mating disruption (Pasqualini and Natale, $1999 \mathrm{a}$ and b).

Suheri et al., (2020) installed delta trap + pheromone of leopard moth in 40 locations at blocks $5^{\text {th }}$ and $6^{\text {th }}$ from May to July 2019 at the Mediterranean region. The highest number (911) of Zeuzera sp. adults was captured from May to July 2019 and the number would possibly increase higher. These results are in agreement with results of the present study where exuvia (excavation of moths) were detected at the period from May to July at the three seasons 2015, 2016 and 2017. In olive orchard, the peak flight of $Z$. pyrina, was from late April to October in Egypt (Hegazi et al., 2015). In addition, Z. pyrina in walnut orchards, Iran, has two flight peaks in May to July and August to September (Navon, 1977). A study by Kutinkova et al. (2006) also showed that Z. pyrina has 2 flight peaks in Bulgaria (Kutinkova et al., 2006). The variation in population dynamics were allegedly due to the species differences of Zeuzera and environmental conditions.

In the present study, active galleries were detected during all the season except May, June and July. Mechanical, chemical and biological methods is suitable for control of leopard moth larvae. Trials to suppress leopard moth larvae using IPM tactics were applied with agricultural processes; pruning and mechanical control, biological control tools using the green lacewing predator release in addition to chemical pesticide (Merghem and Ahmed, 2017). Ismail et al., (1992) stated that, spraying the olive trees with organophosphorus insecticides three times at 3-week intervals (the $1^{\text {st }}$ application in the $2^{\text {nd }}$ week of July) gave better control of the leopard moth.

Finally, an integrated controlling system is needed to control the leopard moth effectively. This integrated pest management program must depend on collaborated several techniques based on several aspects, i.e silviculture, mechanical, biological and chemical. This method was expected to reduce insecticide resistance and create sustainable pest control in the field as it was also stated by Damos et al. (2015). The current study emphasizes on the appropriate time and technique of controlling leopard moth larvae and adults.

\section{REFERENCES}

Abdel-Kawy, A., H. El-Bishry and T. El-Kifl. 1992. Controlling the leopard moth borer, Zeuzera pyrina by three entomopathogenic nematodes in the field. Bull Faculty Agric Cairo Univ. 43: 769-780.
Abed El-Hadi, A., R. Birger, E. Hanoch, Y. Vardi, V. Sarid and B. Zemer. 2005. Control of Zeuzera pyrina in olives by using pheromone male confusing. Alon Ha notea. 59:383-385.

Avilla, J. and D. Bosch. 2001. Mass trapping and mating disruption for the control of leopard moth and apple clearwing moth. IOBC/WPRS Bull. 24:167-172.

Chouinard, G., A. Firlej and D. Cormier. 2016. Going beyond sprays and killing agents: Exclusion, sterilization and disruption for insect pest control in pome and stone fruit orchards. Sci . Horticulturae. 208:13-27.

Damos, P., L. A. E. Colomar and C. Loriatti. 2015. Integrated fruit production and pest management in Europe: the apple case study and how far we are from the original concept? Integrated fruit production and pest management in Europe: the apple case study and how far we are from the original concept? Insects. 6: 626-657.

Hegazi, E., F. Shlyter, W. Khafagi, A. Atwad, E. Agamy and M. Konstantopoulou. 2015. Population dynamics and economic losses caused by Zeuzera pyrina, a cryptic wood-borer moth, in an olive orchard, Egypt. Agricultural and Forest Entomology. 17: 9-19.

Howard, L.O. and F.H. Chittenden. 1916. The leopard moth: 1. Dangerous imported insect enemy of shade trees. USDA, Farmer's Bulletin, Washington, DC. 708.

Ismail, I. I., N. A. Abou-Zeid and F. F. Abdallah. 1992. Population dynamics of the leopard moth, Zeuzera pyrina L., and its control on olive trees in Egypt. J. of Plant Diseases and Protection. 99: 519-524.

Kutinkova, H., R. Andreev and V. Arnaoudov. 2006. The leopard moth borer, Zeuzera pyrina L. (Lepidoptera: Cossidae) important pest in Bulgaria. J. of Plant Protection Research. 46: 112- 115.

Merghem, A. and A. Ahmed. 2017. Leopard moth borer, Zeuzera pyrina L. (Lepidoptera: Cossidae) threat to olive trees, Olea europaea L. (Lamiales: Oleaceae) in Fayoum Governorate and its suppressing trials using IPM tactics. Egypt. Acad. J. Biolog. Sci. 9: 99-107.

Navon, A. 1977. Rearing of the leopard moth Zeuzera pyrina L. on an improved diet. Phytoparasitica. 5: 38-40.

Ntakyo, P.R., J. Mugisha and G. Elepu. 2013. Socio-economic factors affecting apple production in southwestern Uganda. African Crop Sci. J. 21: 311 - 321.

Pasqualini, E. and D. Natale. 1999a. The mating disruption method for Zeuzera pyrina Linnaeus and Cossus cossus Linnaeus (Lepidoptera: Cossidae) control with pheromones. Canard and Beyssat-Arnaouty V. (Eds), Toulouse, France, pp. $177-180$.

Pasqualini, E. and D. Natale. 1999b. Zeuzera pyrina and Cossus cossus (Lepidoptera: Cossidae) control by pheromones. IOBC wprs Bulletin. 22: 115 - 124.

Patanita, M.I. 2006. Control integrado del taladro Amarillo (Zeuzera pyrina L.) en nogales de Alentego (Portugal). Ph.D. dissertation. Universidad de Córdoba, Spain. Google Scholar. 
Suheri, M., N. F. Haneda, Y. H. Jung, S. Sukeno and H. K. Moon. 2020. Effectiveness of pheromone traps for monitoring Zeuzera sp. (Lepidoptera: Cossidae) populations on Eucalyptus pellita plantation. Southeast Asia Plant Protection Conference 2019. IOP Conf. Series: Earth and Environmental Sci. 468: 1 - 7.
Tonini, C., G. Cassani, P. Massardo, G. Guglielmetti and P. L. Castellari. 1986. Study of female sex pheromone of leopard moth, Zeuzera pyrina $\mathrm{L}$. isolation and identification of three components. J. Chemical Ecology. 12: 1545- 1558 .

Yehia, M.M, A. Abd El Bary and A.I. Mohamed. 2016. Improving fruit quality of "Anna cv." apple trees grown on Malus rootstock by some bio compounds. Annals of Agric. Sci., Moshtohor. 54: 919-928.

\section{الملخص العزبي}

الإستدلال على الأطوار المختلفة لحفار ساق التفاح فى بساتين التفاح بمحافظة البحيرة

$$
\text { هويدا محمد توفيق }
$$

ناحيـة أخـرى فـإن عدد جلـود انسـلاخ العـارى وصـل إلـى

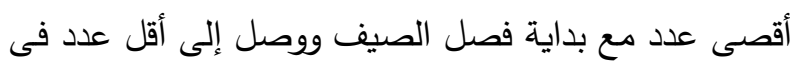
O م يوليو. أثناء الخريف كان هنالك تذبذب خفيف فى أعداد اليرقات (الأنفاق العاملة / • ( شجرات) حيث كان يتراوح من هن r.11 إلى س.r ז خلال الثلاث مواسم المتعاقبة. لم تلاحظ وجـود جـــود إنســلاخ للعـذارى فـى الخريـف والثـتاء خـلال الثلاث مواسـم. هذه الدراسـة تعتبر مفيدة في تحديد أنسـب مواعيد لمكافحة الحشرة الكاملة أو اليرقات لحفار ساق التفاح مـن خـلال إسـتخدام مصــائد فرمونيـة لعمـل تثـتيت تـزاوج

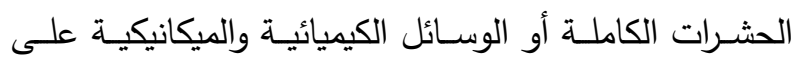
اليرقات من خلال برنامج المكافحة المتكاملة لهذه الأفة.
تم إجراء دراسات حقلية خلاال ثلاث مواسم متعاقبة 0 1 ،

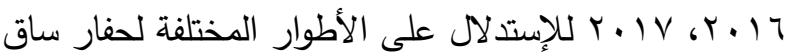
التفاح فى بسـاتين التفـاح فى مركز كفر الدوار - محافظـة

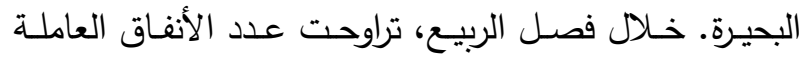

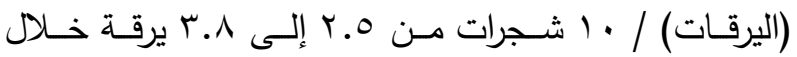

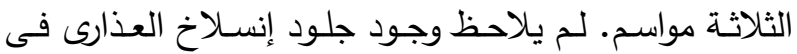

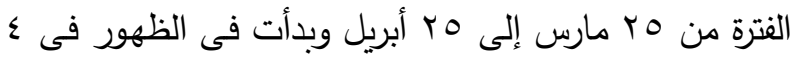

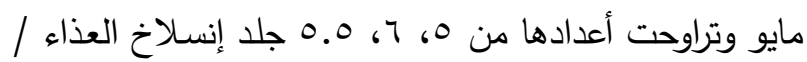

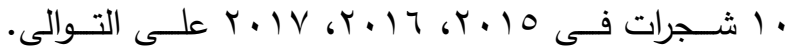
وصل عدد اليرقات / · م شجرات إلى الذروة أثناء الفترة من

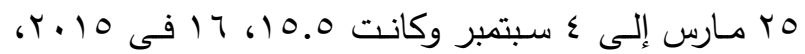

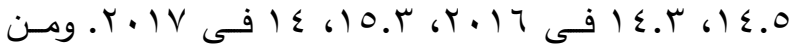

